\title{
Processing of Sour-Sweet Slices of Large Cucumber (Cucumis sativus L.)
}

\author{
Karl Kaack \\ Aarhus University, Kirstinebjergvej 10, 5792 Aarslev, Denmark.
}

\begin{abstract}
This research paper concern processing of large cucumber slices with focus on the effects of processing on quality characteristic of slices promoted by growing cucumber in normal and dry seasons and the second step is concerned about cutting angle by slicing of cucumber halves. The most important quality characteristics are drained weight, firmness, brittleness, lightness L, greenness a, and yellowness that are determined by the quality of the raw cucumbers and processing variable such as peeling, slicing, blanching, cooling, pasteurization, storage time, temperature and storage conditions. Consideration of orientation of the cutting angle showed that it may be necessary to improve the cutting praxis order to make a higher percentage of slices with length as a half circumference of cucumbers weighing one $\mathrm{kg}$. An experiment with blanching of cucumber slices at 70 to $85^{\circ} \mathrm{C}$ showed a linear dependent between slice firmness and a logarithmic relationship at temperatures above $80^{\circ} \mathrm{C}$. At low temperature could this relationship be described using linear functions and the effect of heath at $1{ }^{\circ} \mathrm{C}$ was linear. Data from an experiment with blanching for 1,2 and 4 min at $90{ }^{\circ} \mathrm{C}$ showed that drained weight increased after blanching both before and after slicing. Firmness was significantly low by blanching before slicing, whereas firmness increased significantly by blanching after slicing. Lightness decreased with increasing blanching and storage time and the significantly highest lightness was obtained by blanching after slicing. Greenness, yellowness and lightness decreased significantly by increasing blanching and storage time.
\end{abstract}

Keywords: Cucumber slicing - blanching - firmness - enzymes - browning.

\section{INTRODUCTION}

Sour sweet slices of large cucumber produced in brines with sugar, vinegar and some spices are used as decorations and flavour ingredients upon several kinds of open rye bread sandwiches. The slices are also served as a part of hot dishes together with different kinds of meats, eventually boiled potatoes and other vegetables or spices. The most important quality characteristics of cucumber slices are uniform length, width, weight, colour, aroma, flavour and a brittle texture. Another acquisition by production of sour-sweet cucumber with satisfactory firmness is inactivation of enzymes that may decrease firmness by breaking down cell walls resulting in decreases of texture and cucumber of odour $[1,2,3]$. Inactivation of enzymes may be obtained by pasteurization to inactivation of peroxidases that promote off flavour by oxidation of unsaturated fatty acids $[4,5,6]$. Application of acetic acid or other organic acids in high concentrations may result in decreasing firmness because minerals attacked to vegetable materials exchanges to salt compounds [5]. A high percentage of sugar inversion may occur in the glass jars because of a high slice or brine temperature, slow cooling after packing and by long time of storage by temperatures above $1^{\circ} \mathrm{C}$. Preliminary tests by processing cucumber slices at four factories have shown a high variation in drained weight, slice length, firmness, brines and browning that may reduce consumer acceptability seriously. The average peeling losses were about $15 \mathrm{w} / \mathrm{w} \%$. The temperatures by blanching varied from 79 to $93^{\circ} \mathrm{C}$ and presence of enzyme activity due to non-sufficient blanching were found in several cases. The temperature of cucumber slices by packing varied between 28 and 56\% and the brine temperature varied between 34 and $70^{\circ} \mathrm{C}$ and sugar inversion varied from 7 to100 per cent. Determination of temperature in the pasteurizers varied between 82-90 per cent and the temperature in brine immediately after packing varied between 30 and $54^{\circ} \mathrm{C}$. The most impressive variation was slice lengths $1-22,1-18,1-22$ and $1-15 \mathrm{~cm}$ on four processing units. The maximum slices length was $4-6 \mathrm{~cm}$ corresponding to the width of cucumber halves and a very little amount of the slice had a diameter corresponding to cucumber length. Average slice length on four slicers were 7.5, 7.7, 7.5 and $6.6 \mathrm{~cm}$ with corresponding spreading 3.8, 3.5, 3.7 and 2.9 
$\mathrm{cm}$, respectively. And therefore, it was decided to research in order to improve the quality characteristics of sour-sweet cucumber slices.

\section{Materials ANd Methods}

The field experiment encompassed growing of the cultivar 'Langelandsk Kæmpe'on sandy soil (JBJ), grown according to common horticultural praxis and harvested with average weight one kg. At harvest occurred 2.3 per cent fungous tissue and 97.7 percent normal cucumber and after storage for 4 days without watering occurred 53.5 and 46.5 percent fungous tissue and that is a serious problem. After gently knife peeling by hand was each cucumber sliced longitudinal using a Dito Cutter CCR (Wycombe) in two half pieces named "boots" that were cleaned for seeds and liquids occurring inside the cucumber slices. Without blanching increased firmness from 3.8 to $4.1 \mathrm{~kg}$ by water absorption into air filled tissue cells. Blanching was carried out by keeping the samples at the stipulated temperatures for various times and then cooled in cold water at $12^{\circ} \mathrm{C}$.

Soluble solids were measured using a refractometer (Bellingham Stanley RFM 800) and acidity was determined by titration to $\mathrm{pH} 7.0$ using $0.1 \mathrm{~N}$ sodium hydroxide solution. Surface colours were measured using A Minolta XHTOMA meter (CR-300, Osaka, Japan). Maceration of cucumber tissue in connection with determination of soluble solids and acidity were carried out using four parts of cucumber fruit mixed with one part cold tap water at $12^{\circ} \mathrm{C}$. Materials for analyses were homogenised for two minutes at maximum speed using a Robot-Coupe blender (Model R602VV, Vincennes, Cedex, France) or a hand-held blender (Braun, Miniper Compact, MR 404, Braun Gmbh, Kronberg, Germany). After cooling were $300 \mathrm{~g}$ slices packed in $580 \mathrm{ml}$ glass jars and filled with brine composed of $24.75 \mathrm{~kg}$ water, $18 \mathrm{~kg}$ sugar, $1.125 \mathrm{~g} 80 \%$ acetic acid, $450 \mathrm{~g}$ salt, $450 \mathrm{~g} 10 \%$ potassium sorbate and 225 $\mathrm{ml} 20 \%$ sodium benzoate corresponding to $40,2,1,0.1$ and $0.1 \mathrm{~g} 100 \mathrm{~g}^{-1}$ sugar, acetic acid, salt, potassium sorbate and sodium benzoate. The texture was measured using and Instron Ltd Food Tester instrument with a Kramer-shear cell with velocity $300 \mathrm{~mm} \mathrm{~min}^{-1}$ using sample size $100 \mathrm{~g}$. Measurement of cucumber firmness in the study of firmness in fungous cucumber were carried out using a cylindrical piston with even tip made of stainless steel and placed on the Instron. Samples of raw, cooked and drained cucumber materials for chemical or physical analyses were macerated with a minimum of double distilled water or other liquids using a Waring blender (Waring Products B012-34-BL 99, New Hartford, USA). Inversion of sucrose was measured using a polar meter (Autopol VI Automatic; Rudolph Research Analytica, Newsburg Road, Hachetsttown, NJ, US) and the contents of inverted sugar were determined using $\log _{10} \log _{10}(100 / 100-\mathrm{I})=16.00-\mathrm{pH}-(5570) /(273.16+\mathrm{t})+\log \mathrm{h}$, where $\mathrm{pH}$ is $\log _{10}$ of $\mathrm{H}_{3} \mathrm{O}^{+}$, temperature in ${ }^{\circ} \mathrm{C}$, and $\mathrm{I}$ is the percentage sucrose that was inverted by $\mathrm{h}=0 \min [7]$. The brines used in these experiments were composed of $800 \mathrm{~g}$ sugar, $60 \mathrm{~g}$ acetic acid, $20 \mathrm{~g}$ salt, $20 \mathrm{ml}$ $10 \%$ potassium sorbate, $10 \mathrm{ml} 20 \%$ sodium sorbate and $1900 \mathrm{ml}$ water. The relationship between sensory points and firmness was estimated by ten intensively trained panel members age 25-35 year using a scale from 1 (very soft) to 10 (very hard). Blanched cucumber slices were packed processed slices in glass jars and stored at $3,8,13$ and $19^{\circ} \mathrm{C}$ with 8 samplings after $69,133,225,281,369,439,533$ and 587 days. Cucumber slices were blanched at $75,80,85,90$, and $95^{\circ} \mathrm{C}$ and pasteurized at $95^{\circ} \mathrm{C}$ for 0,1 , $2,4,8,16$ and $20 \mathrm{~min}$. Serious two encompassed blanching at $95^{\circ} \mathrm{C}$ for $4 \mathrm{~min}$ and pasteurization at 95 for $16,32,48,80$ and $96 \mathrm{~min}$ and series three included blanching at $85^{\circ} \mathrm{C}$ for $4 \mathrm{~min}$ and pasteurization at $75^{\circ} \mathrm{C}$ for $16,32,48,46,80$ and $96 \mathrm{~min}$, respectively. The temperature by pasteurization was $44^{\circ} \mathrm{C}$ in the first step and increased to 95, 85 and 72 after 10, 21 and 40min. Pasteurizing was carried out using a similar method by keeping the glass jars with slices in water baths at the estimated temperatures and time, followed by cooling in hot water to $60^{\circ} \mathrm{C}$ for $5 \mathrm{~min}$ and in cold water at $12^{\circ} \mathrm{C}$ for $30 \mathrm{~min}$. The drained weight of cucumber slices after processing and storage were measured after draining of the cucumber materials for $3 \mathrm{~min}$ on a sieve (ASTA II, mesh 7, aperture $2.8 \mathrm{~mm}$ ). Surface colour of cucumber slices was measured using a Hunter colorimeter by determination of lightness L, greenness a and yellowness $b$ intriplicates. The statistical methods included linear and logarithmic regression, analysis of variance, factor analysis and response surfaced methodology using a Statgraphic Statistical Package (Statistical Graphics, Version 4, Rockville, USA). Averages were separated using letters. Factor analysis encompassed varimax rotation of normalized data and a scree test were carried out according to $[8,9,10]$.

\section{Results}

Processing of cucumber with 2.3 percent fungous cucumber and 97.7percent normal tissue resulted in difficulties by occurrence of air-filled tissue inside the cucumber slices. After storage of these cucum- 
bers for four days was the percentage of slices with fungous tissue 37 and $63 \%$, respectively. Storage for eight days resulted in $100 \%$ fungous tissue in all cucumbers. Irrigation or storage in water resulted 86.4 and $15.6 \%$ fungous and none normal cucumbers after eight days, respectively. These data showed that the degree of fungous cucumber tissue increased almost relentless during storage of cucumber slices. The last experiment with treatment of fungous tissue in large cucumber slices were carried out by keeping the samples of cucumber slices in a pressure pot with brine and establishment of vacuum in this pot for $15 \mathrm{~min}$. That resulted in disappearance of the fungus tissue, absorption of brine and increases in cucumber texture. After uptake of liquid did the cucumber slice have a texture as normal cucumber slices and their firmness were non-significantly different.

Table 1. Distribution of cucumber slice length.

\begin{tabular}{|l|c|c|c|c|c|}
\hline & \multicolumn{5}{|l|}{ Cutting angle, $^{\text {o }}$} \\
\hline Cutting angle & $0-10$ & $0-30$ & $0-50$ & $0-70$ & $0-90$ \\
\hline Length, mm & $99 \mathrm{a}$ & $101 \mathrm{~b}$ & $105 \mathrm{c}$ & $114 \mathrm{~d}$ & $123 \mathrm{e}$ \\
\hline Variation, mm & $74-124$ & $57-146 \mathrm{~b}$ & $45-165 \mathrm{c}$ & $17-211 \mathrm{~d}$ & $0-265 \mathrm{e}$ \\
\hline
\end{tabular}

Development of softness in cucumber was companied by conversion of non-soluble protopectins to soluble pectin substances. And besides may pectin esterase promote exchange of methyl groups with monovalent minerals that may increase firmness as described previously $[10,11,12,13,14]$. This may occur until removal of a low percentage of methyl groups [13]. The average of slice thickness was 7.8 $\mathrm{mm}$ with slice length from 3.3 to $6.3 \mathrm{~cm}$. After removal of the seeds and liquid in the two halves they were cut transversal into $7.8 \mathrm{~mm}$ slices with standard deviation $0.6 \mathrm{~mm}$. The average slice thickness of cucumber slices after storage for five months were $7.8 \mathrm{~mm}$ with standard deviation $0.6 \mathrm{~mm}$, the slice length was $4.8 \mathrm{~cm}$ with standard deviation $0.76 \mathrm{~cm}$ and the average weight was $6.1 \mathrm{~g}$ with standard deviation $0.5 \mathrm{~g}$. Modelling of slice length was carried out by considering each half of acucumber as a rectangular piece with length $\mathrm{k}$, slice thickness $\mathrm{t}$ and the right cutting angle was $90^{\circ}$. Using parallel knives may the cutting result in the maximum number of short slices be equal in length as the half of the cucumber circumstance. The number of slices will be $n=1 / t(k \operatorname{cosv}-b \sin v)$ with length $p=$ $\mathrm{b} / \mathrm{cos} \mathrm{v}$. If the cutting angle to the flat rectangular cucumber pieces increases above $90^{\circ}$ will the slice length be $\mathrm{n}=\mathrm{k} / \sin \mathrm{v}$ and the number of slices will increase to $(\mathrm{x}-\mathrm{nt}) /(\cos \mathrm{v} \cdot \sin \mathrm{v})$. Slice thickness were $7.8 \mathrm{~mm}$ with standard deviation $\mathrm{s}=0.6 \mathrm{~mm}$ and the slice length varied from $3.3-6.3 \mathrm{~cm}$ and the average weight were $6.1 \mathrm{~g}$. The firmness of slices increased linearly with the amount of materials in the sample cell according hkg $=1.7+0.016 \mathrm{~g}$ and the sensory point from sensory analysis increased linearly with slice firmness: $\log$ point $=-0.037+2.17 \log (\mathrm{kg}) ; \mathrm{r}=0.995$.

Sensory evaluation were carried out by a panel with four women and four men trained for five years in evaluation of the cucumber, peas, spinach, lettuce, green beans, carrot using a scale from 1 to 10 corresponding to a minimum and maximum of a variety of sensory properties including texture, surface colour, sweetness, sourness and sweetness. And the relationship between sensory evaluated firmness in comparison to firmness measured using an Instron apparatus were $\log$ (point) $=-0.037+2.171$ $\log$ (firmness).

Table 2. Blanching and pasteurization.

\begin{tabular}{|c|l|c|l|c|}
\hline Min $/{ }^{\circ} \mathrm{C}$ & Blanching & $\mathrm{P}$ & Pasteurization & $\mathrm{P}$ \\
\hline 0 & $\log \mathrm{kg}=0.52+0.00086^{\circ} \mathrm{C}$ & $* * *$ & $\log \mathrm{kg}=0.62-0.01627^{\circ} \mathrm{C}$ & $* * *$ \\
\hline 1 & $\log \mathrm{kg}=3.25-0.0076{ }^{\circ} \mathrm{C}$ & $* * *$ & $\log \mathrm{kg}=0.59-0.01625 \mathrm{~min}$ & $* * *$ \\
\hline 75 & $\log \mathrm{kg}=0.60-0-000685 \mathrm{~min}$ & $* * *$ & $\log \mathrm{kg}=4.25-0.00937^{\circ} \mathrm{C}$ & $* * *$ \\
\hline 80 & $\log \mathrm{kg}=0.63-0.0693, \mathrm{~min}$ & $* * *$ & $\log \mathrm{kg}=3.96-0.029^{\circ} \mathrm{C}$ & $* * *$ \\
\hline
\end{tabular}

Slice firmness decreased according to log functions linearly with blanching and pasteurization time (Table 2). Without blanching was lightness (L) 63 and blanching for 1 min reduced lightness to between 52 and 54 and resulted in removal of air tissues by absorption of brine. Without blanching increased the cucumber firmness with increasing pasteurization time. If the samples were blanched for 1 min decreased the firmness with pasteurization up to $95^{\circ} \mathrm{C}$. The data presented in equation 1 showed that firmness increased if the blanching time was zero, which could be a result of enzyme activity of several enzymes that exchange metoxy groups on the pectin with minerals McFeeters [12]. These data was confirmed by significantly increasing pectin methylation from $44 \%$ without heat treatment to $56.8 \%$ after blanching at four temperatures $\left(54,66,81\right.$ and $\left.99^{\circ} \mathrm{C}\right)$ that also resulted in more firm cucumberslices [12]. Excess of softening may occur because pectins stored in the slices and the brine is 
degraded to smaller molecules that easily may be degraded and eventually used for other purposes [13]. Pasteurization of cucumber slices in glass jars at 75,80,85,90 and $95^{\circ} \mathrm{C}$ for $0,4,8,12,16,20$ min resulted in significantly decreasing firmness. A centre temperature above $72{ }^{\circ} \mathrm{C}$ was obtained after 8 , 15 and 28 min by pasteurizing at 95,85 and $75^{\circ} \mathrm{C}$. The strong relationship between sensory properties and technical measurement of firmness has been confirmed [14]. The effect of the temperature at 75 and $95^{\circ} \mathrm{C}$ on the changes of firmness by pasteurization could be described using a logarithmic relation, respectively (Table 2).

Drained weight increased significantly with increasing blanching time both before and after slicing (Table 2). Firmness decreased significantly with blanching time before slicing and increased significantly with time by blanching after slicing. The reason may be that blanching before slicing not caused elimination of the air cells, whereas blanching after slicing caused easier elimination of air from the cucumber slices by polygalacturonase and postharvest holding conditions of cucumber resulting in exchange of the white air cells with brine [15]. That may be due to enzyme activity, changes in sugar composition in cucumber cell walls [16,17]. Similar changes may occur during postharvest holding conditions and mechanical harvesting $[18,19]$. The activity of pectinesterase are very important because demethylation are necessary in order to use the possibility of increasing texture firming because by association of calcium ions between pectin chains result in more firm cucumber slices by reduction in the removal pectinmethylesterase [20]. The cucumber firmness increased linearly by increasing contents of cell wall sugars, total contents of sugars and galacturonic acid and by increasing pectin methyl association[21]. Such increments in firmness may also occur in other vegetables [21]. The association of calcium with the contents of the contents of pectin esterase has been documented very intensively [22]. Lightness decreased significantly by increasing blanching time both before and after blanching and the highest lightness was obtained by blanching after slicing. The significantly highest lightness by blanching occurred by blanching after slicing, because the air cells were eliminated easier by shortening the distances for air removal.

Table 3. Effects of blanching and storage time and cutting before or after slicing $(n=4)$.

\begin{tabular}{|l|c|c|c|c|c|c|c|c|c|c|c|c|c|}
\hline & \multicolumn{10}{|c|}{ Blanching time, min } & \multicolumn{4}{|c|}{ Storage time, months } \\
\hline Min & 1 & 2 & 4 & 1 & 2 & 4 & 1 & 2 & 4 & 1 & 2 & 3 & 4 \\
\hline & Drained weight, $\mathrm{g}$ & \multicolumn{3}{|c|}{ Firmness, $\mathrm{kg}$} & \multicolumn{3}{|c|}{ Lightness, L } & \multicolumn{5}{|c|}{ Lightness, L } \\
\hline Before & $317 \mathrm{c}$ & $333 \mathrm{~b}$ & $337 \mathrm{a}$ & $467 \mathrm{ap}$ & $422 \mathrm{bp}$ & $333 \mathrm{cq}$ & $73 \mathrm{ap}$ & $59 \mathrm{bq}$ & $55 \mathrm{cq}$ & $83 \mathrm{~b}$ & $56 \mathrm{bq}$ & $36 \mathrm{cq}$ & $54 \mathrm{bq}$ \\
\hline After & $311 \mathrm{c}$ & $318 \mathrm{~b}$ & $341 \mathrm{a}$ & $386 \mathrm{aq}$ & $405 \mathrm{bq}$ & $427 \mathrm{ap}$ & $74 \mathrm{ap}$ & $69 \mathrm{bp}$ & $64 \mathrm{cq}$ & $92 \mathrm{a}$ & $59 \mathrm{cp}$ & $63 \mathrm{bp}$ & $62 \mathrm{bp}$ \\
\hline
\end{tabular}

By storage from one to four months was lightness lowest by blanching before slicing and blanching after slicing resulted in higher lightness after removal of the air filled cells. Blanching for 1 to 4 min resulted in decreasing greenness, yellowness and lightness as found previously (Table 3). Elimination of air tissue resulted in a more attractive colour because a higher amount of brine was absorbed. Drained weight decreased significantly by increasing blanching time and the highest drained weight was obtained by blanching before slicing. Greenness decreased, while yellowness and lightness increased significantly by blanching after cutting and increasing blanching time resulted in decreases in the three colours. Storage of cucumber slices resulted in significantly decreases in greenness, yellowness and lightness (Table4).

Table 4. Effects of processing on surface colour of cucumber slices

\begin{tabular}{|l|c|c|c|c|c|c|c|c|c|}
\hline Colour & \multicolumn{2}{|c|}{ Slicing } & \multicolumn{3}{c|}{ Blanching, min } & \multicolumn{4}{c|}{ Storage, months } \\
\hline & Before & After & 1 & 2 & 4 & 1 & 2 & 3 & 4 \\
\hline Greenness, $\mathrm{a}$ & $-4.0 \mathrm{a}$ & $-3.5 \mathrm{~b}$ & $-4.3 \mathrm{a}$ & $-3.8 \mathrm{~b}$ & $-3.4 \mathrm{c}$ & $-4.3 \mathrm{a}$ & $-3.6 \mathrm{~b}$ & $-3.6 \mathrm{~b}$ & $-3.0 \mathrm{c}$ \\
\hline Yellowness, $\mathrm{b}$ & $12.6 \mathrm{a}$ & $16.9 \mathrm{~b}$ & $16.5 \mathrm{a}$ & $13.8 \mathrm{~b}$ & $14.1 \mathrm{~b}$ & $14.0 \mathrm{a}$ & $12.8 \mathrm{~b}$ & $12.2 \mathrm{~b}$ & $12.1 \mathrm{~b}$ \\
\hline Lightness, L & $62.5 \mathrm{~b}$ & $69.1 \mathrm{a}$ & $73.4 \mathrm{a}$ & $64.4 \mathrm{~b}$ & $59.6 \mathrm{c}$ & $87.7 \mathrm{a}$ & $59.8 \mathrm{a}$ & $59.2 \mathrm{a}$ & $57.5 \mathrm{~b}$ \\
\hline
\end{tabular}

Data from an experiment with varying temperature and time showed that slicing before blanching for 1,2 and $4 \mathrm{~min}$ resulted in significantly increases in drained weight, while blanching after slicing resulted in significantly higher firmness and drained weight (Table 5). Drained weight increased significantly with storage time both before and after blanching and blanching before slicing resulted in a significantly higher drained weight than blanching after slicing. Processing and storage did not affect the contents of soluble solids and acidity. Besides these effects was lightness (L) significantly higher during storage if they were sliced before blanching. The softening of cucumber tissues take place as a first order reaction using three pectinases combined with changes in salt levels that may be counter- 
acted by increases in salt from a low percentage were softening are high to a high level of salt that decrease the relative softening. These studies included studies of the effects of blanching and storage time $33,69,133,225,281,369,439,533$ and 587 days after storage at $3,8,13$ and $18^{\circ} \mathrm{C}$. Drained weight and firmness increased significantly with blanching time, lightness decreased with blanching time, whereas the effects on colorants were unclear. An experiment encompassing storage of cucumber slices up to 342 days showed that drained weight increased significantly up to 281 days and decreased significantly by longer blanching time. Because of this stop in drained weight it was concluded that the maximum for increasing drained weight were obtained after 342 days of storage. Lightness and greenness decreased, while yellowness and colour differences increased significantly. An experiment with increasing storage time showed that drained weight increased significantly up to 307 and 268g before and after slicing, respectively. Processing and storage did not affect the contents of soluble solids and acidity significantly during processing or storage (Table 5).

Table 5. Effects of storage time on drained weight, soluble solids, acidity.

\begin{tabular}{|c|c|c|c|c|c|c|c|c|c|c|}
\hline \multirow[t]{2}{*}{ Months } & \multicolumn{2}{|c|}{ Drained weight, $g$} & \multicolumn{2}{|c|}{$\begin{array}{l}\text { Soluble solids } \\
\text { g } 100 \mathrm{~g}^{-1}\end{array}$} & \multicolumn{2}{|c|}{$\begin{array}{l}\text { Acidity } \\
\text { g } 100^{\mathrm{g}-1}\end{array}$} & \multicolumn{2}{|c|}{$\begin{array}{l}\text { Soluble solids } \\
\text { g } 100 \mathrm{~g}^{-1}\end{array}$} & \multicolumn{2}{|c|}{$\begin{array}{l}\text { Acidity } \\
\text { g } 100 \mathrm{~g}^{-1}\end{array}$} \\
\hline & before & after & before & after & before & after & before & after & before & after \\
\hline 1.1 & $289 \mathrm{~cd}$ & $215 \mathrm{~d}$ & $20.0 \mathrm{a}$ & $19.7 \mathrm{a}$ & $1.13 \mathrm{a}$ & $1.16 \mathrm{a}$ & $19.3 \mathrm{a}$ & $19.8 \mathrm{~b}$ & $1.09 \mathrm{a}$ & $1.11 \mathrm{a}$ \\
\hline 2.2 & $299 \mathrm{bq}$ & $225 \mathrm{c}$ & $20.8 \mathrm{a}$ & $20.2 \mathrm{a}$ & $1.16 \mathrm{a}$ & $1.15 \mathrm{a}$ & $20.4 \mathrm{a}$ & $20.5 a$ & $1.12 \mathrm{a}$ & $1.10 \mathrm{a}$ \\
\hline 3.1 & $297 \mathrm{bq}$ & $256 \mathrm{bq}$ & $19.5 \mathrm{~b}$ & $20.3 \mathrm{a}$ & $1.09 \mathrm{a}$ & $1.07 \mathrm{a}$ & $19.7 b$ & $19.9 \mathrm{a}$ & $1.06 \mathrm{a}$ & $1.11 \mathrm{a}$ \\
\hline 3.7 & 308ap & $256 \mathrm{bq}$ & $29.9 a$ & $20.2 \mathrm{a}$ & $1.15 \mathrm{a}$ & $1.14 \mathrm{a}$ & $20.6 \mathrm{a}$ & $20.6 \mathrm{a}$ & $1.11 \mathrm{a}$ & $1.10 \mathrm{a}$ \\
\hline 6.0 & 307ap & 268ap & $19.9 \mathrm{a}$ & $19.8 \mathrm{a}$ & $1.12 \mathrm{a}$ & $1.10 \mathrm{a}$ & $20.3 a$ & $20.3 a$ & $1.08 \mathrm{a}$ & $1.06 \mathrm{a}$ \\
\hline
\end{tabular}

During preparation and filling of jars with brine should the temperature be kept below $20^{\circ} \mathrm{C}$ because a high temperature may result in inversion of sucrose and release fructose which may interact with nitrogen compounds and produce brown compounds. Factoranalysis of the data from four factories resulted in extraction of three eigen values 3.28, 2.49,0.64 and corresponding 47.4, 35.9 and 9.2 percentage of the variance and totally $92.5 \%$ of the data variation. Factor 1 had significantly negative contributions from acetic acid, factories, soluble solids and sucrose inversion (Table 6), whereas drained weight and $\mathrm{NaCl}$ contributed significantly positive to factor 1 . Factor 2 had three positive and significantly contributions from acetic acid, brine and drained weight.

Table 6. Effects of blanching and storage time on drained weight $\mathrm{g}$, firmness $\mathrm{kg}$, lightness $\mathrm{L}$, greenness a, yellowness $b$ and colour difference $\Delta E$.

\begin{tabular}{|c|c|c|c|c|c|c|}
\hline Min & Weight, $\mathrm{g}$ & Firmness, $\mathrm{kg}$ & Lightness, L & Greenness, a & Yellowness, $\mathrm{b}$ & $\Delta \mathrm{E}$ \\
\hline 0 & $300 \mathrm{c}$ & $321 \mathrm{~b}$ & $64 \mathrm{a}$ & $-1.6 \mathrm{~b}$ & $23 \mathrm{a}$ & $18 \mathrm{~b}$ \\
\hline 1 & $343 \mathrm{~b}$ & $365 \mathrm{a}$ & $60 \mathrm{~b}$ & $-1.0 \mathrm{a}$ & $19 \mathrm{c}$ & $18 \mathrm{~b}$ \\
\hline 3 & $365 \mathrm{a}$ & $396 \mathrm{c}$ & $59 \mathrm{c}$ & $-1.5 \mathrm{~b}$ & $20 \mathrm{~b}$ & $22 \mathrm{a}$ \\
\hline${ }^{\circ} \mathrm{C}$ & & & & & & \\
\hline 3 & $333 \mathrm{c}$ & $336 \mathrm{a}$ & $62 \mathrm{a}$ & $-2.5 \mathrm{~d}$ & $19 \mathrm{c}$ & $16 \mathrm{~d}$ \\
\hline 8 & $336 \mathrm{~b}$ & $328 \mathrm{~b}$ & $61 \mathrm{~b}$ & $-1.8 \mathrm{c}$ & $21 \mathrm{~b}$ & $18 \mathrm{c}$ \\
\hline 13 & $336 \mathrm{~b}$ & $323 \mathrm{c}$ & $59 \mathrm{c}$ & $-0.7 \mathrm{~b}$ & $20 \mathrm{~b}$ & $20 \mathrm{~b}$ \\
\hline 18 & $339 \mathrm{a}$ & $321 \mathrm{~d}$ & $57 \mathrm{~d}$ & $-0.3 \mathrm{a}$ & $22 \mathrm{a}$ & $22 \mathrm{a}$ \\
\hline Month & & & & & & \\
\hline 2.3 & $332 \mathrm{a}$ & $330 \mathrm{a}$ & $65 \mathrm{a}$ & $-3.0 \mathrm{f}$ & $14 \mathrm{c}$ & $22 \mathrm{~b}$ \\
\hline 4.4 & $335 \mathrm{a}$ & $330 \mathrm{a}$ & $64 \mathrm{a}$ & $-2.8 \mathrm{e}$ & $15 \mathrm{~d}$ & $21 \mathrm{c}$ \\
\hline 7.5 & $338 \mathrm{a}$ & $322 \mathrm{a}$ & $63 \mathrm{a}$ & $-2.6 \mathrm{~d}$ & $16 \mathrm{c}$ & $20 \mathrm{c}$ \\
\hline 9.4 & $342 \mathrm{a}$ & $327 \mathrm{a}$ & $62 \mathrm{~b}$ & $-2.0 \mathrm{c}$ & $17 \mathrm{~b}$ & $20 \mathrm{c}$ \\
\hline 12.3 & $340 \mathrm{a}$ & $329 \mathrm{a}$ & $61 \mathrm{c}$ & $-1.5 \mathrm{~b}$ & $20 \mathrm{~b}$ & $23 \mathrm{a}$ \\
\hline 14.6 & $327 \mathrm{a}$ & $327 \mathrm{a}$ & $60 \mathrm{~d}$ & $-1.2 \mathrm{~b}$ & $20 \mathrm{~b}$ & $22 \mathrm{~b}$ \\
\hline Month & & & & & & \\
\hline 2.3 & $332 \mathrm{e}$ & $330 \mathrm{a}$ & $65 \mathrm{a}$ & $-3.4 \mathrm{~g}$ & $22 \mathrm{~b}$ & $14 \mathrm{f}$ \\
\hline 4.4 & $335 \mathrm{~d}$ & $330 \mathrm{a}$ & $64 \mathrm{a}$ & $-3.0 \mathrm{f}$ & $21 \mathrm{c}$ & $15 \mathrm{e}$ \\
\hline 7.5 & $338 \mathrm{c}$ & $322 \mathrm{~d}$ & $63 \mathrm{ab}$ & $-2.6 \mathrm{e}$ & $20 \mathrm{~d}$ & $16 \mathrm{~d}$ \\
\hline 9.4 & $342 \mathrm{a}$ & $327 \mathrm{~b}$ & $62 \mathrm{~b}$ & $-2.0 \mathrm{~d}$ & $20 \mathrm{~d}$ & $17 \mathrm{c}$ \\
\hline 12.3 & $340 \mathrm{~b}$ & $329 \mathrm{~b}$ & $61 \mathrm{c}$ & $-1.5 \mathrm{c}$ & $23 \mathrm{a}$ & $20 \mathrm{~b}$ \\
\hline 14.6 & $334 \mathrm{~d}$ & $327 \mathrm{c}$ & $60 \mathrm{c}$ & $-1.2 \mathrm{~b}$ & $22 \mathrm{~b}$ & $20 \mathrm{~b}$ \\
\hline 17.8 & $332 \mathrm{e}$ & $323 \mathrm{~d}$ & $57 \mathrm{a}$ & $-0.5 \mathrm{a}$ & $20 \mathrm{~d}$ & $21 \mathrm{a}$ \\
\hline 19.6 & $336 \mathrm{~d}$ & $324 \mathrm{~d}$ & $58 \mathrm{a}$ & $-0.3 \mathrm{~h}$ & $19 \mathrm{e}$ & $21 \mathrm{a}$ \\
\hline
\end{tabular}

$\mathrm{Lo}=\left[\left(\mathrm{L}_{0}-\mathrm{L}\right)^{2}+\left(\mathrm{a}_{0}-\mathrm{a}\right)^{2}+\left(\mathrm{b}_{0}-\mathrm{b}\right)^{2}\right]^{0.5} \mathrm{~L}_{0}=75 ; \mathrm{a}_{0}-5 ; \mathrm{b}_{0}=10$. 
Factor three had one significantly negative contribution from the bottles. The communalities show that acetic acid, brine, drained weight, $\mathrm{NaCl}$, factory, soluble solids and sucrose inversion contributed significantly to the factor loadings. Factor one and two could be named sour, salty, drained non sweet cucumber, acid drained brine, while factor 3 could be called minus bottle (Table 8). Data from this experiment showed that increasing storage temperature resulted in significantly increases of drained weight, whereas firmness and lightness decreased significantly (Table 6). Greenness, yellowness, firmness, lightness and greenness decreased significantly, while yellowness and $\Delta \mathrm{E}\left(\mathrm{L}_{0},=75 ; \mathrm{a}_{0}=-5\right.$, $\left.b_{0}=10\right)$ increased significantly (4). Data from storage of slices at increasing temperature resulted in significantly increases of drained weight, whereas firmness and lightness decreased significantly (Table 6).Greenness, yellowness and firmness, lightness and greenness decreased significantly, while yellowness and $\Delta \mathrm{E}\left(\mathrm{L}_{0}=75 ; \mathrm{a}_{0}=-5, \mathrm{~b}_{0}=10\right)$ increased significantly.

During blanching of cucumber slices decreased drained weight, firmness and lightness decreased with storage time from 3 to with blanching and storage time. Drained weight increased, while firmness and lightness decreased significantly with increasing blanching time by processing of cucumber slices. Lightness decreased significantly with storage time from one to four months. Whereas lightness decreased with increasing storage time by increased blanching time. Firmness decreased significantly by increasing blanching time before cutting and increased by cutting after blanching. Drained weight and firmness increased by increasing blanching time, lightness decreased, greenness and yellowness had minimums and $\Delta \mathrm{E}$ increased by increasing blanching time for 0 to $3 \mathrm{~min}$ (Table 6). Drained weight, yellowness and $\Delta \mathrm{E}$ increased during storage, whereas firmness and lightness decreased by increasing storage temperature. Drained weight increased up to storage for 9.4 months and decreased thereafter during the remaining storage time. Yellowness had a maximum after 12.3 months of storage. Firmness, lightness, and greenness decreased, whereas $\Delta \mathrm{E}$ increased during long storage time (Table 6). Drained weight increased, while firmness and lightness decreased significantly with increasing blanching time by processing of cucumber slices (Table 6). Lightness decreased significantly with storage time from one to four months. Whereas lightness decreased with increasing storage time by increased blanching time. Firmness decreased significantly by increasing blanching time before cutting and increased by cutting after blanching. Lightness decreased by increasing blanching time and blanching after cutting resulted in significantly higher lightness. Lightness decreased significantly with storage time and cutting after blanching resulted in this experiment included studies of the effects blanching time storage time $69,133,225,281,369,439,533$ and 587 days after storage at $3,8,13$ and $18^{\circ} \mathrm{C}$. Damage of the cell walls by vacuum treatment of cucumber slices may improve the equilibration rate $[23,24,25]$ as found by processing of mushroom slices $[26,27]$ that also may affect the cucumber texture [28]. Besides it has been found that vacuum soaking and ultrasonic treatments assisted blanching improve size variation, heat transfer, and quality parameters of mushrooms [29]. Browning of cucumber slices may occur due to reaction between sugars and amino acids, caramelization, oxydation, enzyme reactions and the most important colorants are chlorophyll, anthocyanin and betacyanin, stepwise increases from first treatment that in cucumber may be peeling, blanching and storage time. This method require measurement of soluble solids, $\mathrm{pH}$, percentage inversion of sucrose (polarimetry), absorbance of filtered brine (420nm), firmness of drained slices (Instron piston $50 \mathrm{~mm} \mathrm{~min}^{-1}$ ) and colour (Yellow index per ASTM D) (1925-70) called YI -1 measured using a Hunter colorimeter. The CEI tristimulus values X, Y, Z are used for determination of YI-1 $=(100(1.28-\mathrm{X}-1.06 \mathrm{Z}) / \mathrm{Y}$. Industrial processing of cucumber slices is based on supply of fruits weighing about one $\mathrm{kg}$ and a high share of uniformity without bended fruits. The inside white tissue occurring between the seed cavity and the firm mesocarp of cucumber consist of air filled fungous layer that often appear on the inside area of cucumber slices. However, series of scientific experiments showed that the white tissue is due to air filled cell areas that could be removed using vacuum treatments [30]. Because of similarity to white tissue it was considered that occurrence of fungous tissue also could be due to air filled cells developed during a fast cucumber fruit growth by lack in water supply and uptake because of the weather conditions. Occurrence of fungous tissue in cucumber is detrimental to the fruit quality. Pectins are important constituents in the middle lamella of cell walls of fruit and vegetables where they are stabilizing the cell walls by adhesion to other cells walls with cellulose fibre and a diversity of other carbohydrates. During maturation, storage conditions and by processing may occur changes catalysed by enzymes that cause changes in freshness, firmness, softness and their solubility [31,32]. During maturation of cucumber fruits were the contents of sugars in the mesocarp linearly related to fruit diameter and the fruit firmness, galacturonic acid and pectin methylation increased linearly with sugar content in the cell wall [33]. Cucumber peel tissue contained 4-5-fold higher sugar content than 
either mesocarp of endocarp tissues and the major neutral sugars galactose, xylose and mannose declined during fruit development [34] and the relationships among cell wall constituents, calcium and texture during cucumber increased by fermentation and storage [17,34]. Increasing cucumber temperature resulted in loss of firmness and respiration rates may increase weight loss and a decrease in the final quality product quality [18]. Pectinesterase activity, pectin methylation and texture changes may occur in the first phase of processing and increases may occur already during washing and considerably during blanching and by storage of blanced cucumber slices. Plant pectinases catalyses demethylation of pectins are generally rather heat stable and their action on increasing temperature up to $99^{\circ} \mathrm{C}$ resulted in decreasing pectinesterase activity, pectin methylation and increased mesocarp firmness $[1,17,11,18]$. Decreases in firmness during blanching may result in pectin methylation and increases of mesocarp firmness $[18,19,20]$. Pectin esterase in cucumber may result in a stronger polypectate gel after demethylation [23]. Pectinesterase activity, pectin methylation, and texture changes during storage of blanched cucumber slicesand may act in relation to pectin methylation ranging from 9 to $48 \%$.The contents of pectins increased with blanching temperature as shown in equation 3-7 above. Activity of endo- and exo-polygalacturonase from cucumber results in dividing pectin into polygalacturonates with lower molecule weight according to logarithmic functions $[1,2,3]$. The changes in textural properties including brittleness, firmness, cohesiveness, elasticity, gumminess and chewiness depended significantly on cucumber varieties. Raising activity of endo- and exopolygalaturonase activity is followed by destruction of the cucumber firmness and even residual cucumber polygalacturonase may be associated to softening of cucumber tissue [28]. Blanching of cucumber at $81^{\circ} \mathrm{C}$ resulted in complete inactivation of pectinesterase during storage, but $15-20 \%$ reactivation was observed [11]. Complete inactivation of both exo- and endo-polygalacturonase was obtained by heating the cucumber tissue to $90{ }^{\circ} \mathrm{C}$ for $15 \mathrm{~min}$ according to [26]. Non-blanching and blanching of cucumber mesocarp in distilled boiling water for 3 min resulted in a small increase in firmness from 8.7 to $10.1 \mathrm{~N}$ and non-significantly differences in eight monosaccharide compounds [11]. The relationship between degradation of cucumber tissue is often logarithmic as found for the effects of time and temperature by blanching and pasteurization by presence of both exo- and endopolygalacturonase that activity [26,27,28]. Pasteurization of cucumber at temperatures between 71 and $76{ }^{\circ} \mathrm{C}$ followed by fast cooling was found to decrease spoilage and resulted in high quality of cucumber [29]. Optimum degree of esterification in order to obtain an optimum firmness was between 10 and $12 \mathrm{~N}$ [13]. Immediately after addition of brine to the jars with the blanched cucumber slices diffuse solutes into the slices and the brine solutes including sugar, acetic acid, salt and all soluble compounds diffuse into the cucumber slices until equilibration is obtained after a few days [3,21,29]. Experimental packs of pasteurized cucumbers were treated with pectinase from three sources under controlled conditions with respect to temperature, $\mathrm{pH}$, acidity, salt concentration, and absence of microbial development. The effect of blanching time on lightness resulted in darker slices with $\mathrm{L}=62.5$ by slicing before blanching in comparison to slicing after blanching that was $\mathrm{L}=69.1$. This means that slicing after blanching resulted in significantly higher lightness and yellowness, while greenness increased in comparison to slicing before blanching (Table 5). Increasing blanching time reduced greenness, yellowness and lightness significantly. According to these data may the most green, yellow and highest lightness be obtained after blanching for one minute and after short storage. Development of brown colorants during storage of cucumber is due to presence of polyphenol oxidase peroxidase and polyphenol oxidase [30]. Polyphenol oxidase present in cucumber catalyses hydroxylation of monophenols to o-diphenoles and oxidation of these diphenols to O-quinones known as diphenolase activity. Polyphenol oxidase present in cucumber catalyses hydroxylation of monophenols to $\mathrm{O}$ diphenoles and oxidation of these diphenol to O-quinones are known as diphenolase activity. These activities result in formation of dark brown polymers of a quinoidal nature [34]. The browning of cucumber is promoted by peroxidases $[22,35,36]$. A large variation in slice length reduce the quality because this decrease the quality in comparison to homemade slices and may be improved by optimization of slicer feeding mechanism. There is a considerable variation between and within temperature of blanching water at factory one and three and the variation in slice temperature after blanching. The brine temperature is too high in factory 1,2,3 and varies more than necessary. Concentration and variation in acetic acid and soluble solids is perfect whereas sucrose inversion is too high for factory 2 and 3 and that will increase browning on stock, super market and by the byers. Pasteurizer temperature and slice temperature after packing was satisfactory. Inversion of 93 and 100\% are not acceptable. There is significantly difference between in all quality characteristics except $\mathrm{pH}$ that may be determined by each of the managers. The data from factor analysis are very interesting according to - 
0.63 and -0.64 because of bottle and factory (Table 8). Data from evaluation of slices processed at four factories showed that slice length varied in length from 1-15 cm for factory 4 and from 2 to 22 $\mathrm{cm}$ at factory. The average blanching temperature varied significantly from 77 to $90^{\circ} \mathrm{C}$ between factories and there was a considerable variation in the temperature of blanching water. The slice temperature after blanching and cooling varied from 31 to $51^{\circ} \mathrm{C}$. The brine temperature varied significantly between factories. The variation in soluble solids was fair, whereas the large differences in sucrose inversion may be fatal because increases in the content of inversed sucrose may result in browning during the first weeks of cold storage. Unsatisfactory heat treatment increases the possibility for changes in the activity of enzymes that may decrease firmness because of hydrolysis of pectin compounds. Another example is enzymatic inversion of sucrose to glucose and fructose that increases the possibility for increased browning during storage of cucumber slices. The significantly different content of acetic acid and soluble solids between processors may be due to consumer preferences regarding flavour, colour and firmness. Blanching temperature above $75^{\circ} \mathrm{C}$ and slice temperature above $40^{\circ}$ $\mathrm{C}$ after blanching and packing using a brine temperature above $80^{\circ} \mathrm{C}$ may cause serious significantly decreases in firmness and browning and almost complete inversion of sucrose that promote browning. One-way analyses of slice length showed that the four groups of slices had similar non-significantly different size with average size 13 and standard residue zero $(n=25)$. That means that the four groups of slices from the four factories were non-significantly different with slice length $=16.2-0.05272$ number of slices with $P<0.01$ and $r=-0.712$. Drained weight $(G)$ depended significantly positive on blanching time $(\mathrm{T})$ and storage temperature $(\mathrm{C})$ and negatively on the square of temperature $\left(\mathrm{T}^{2}\right)$. The coefficient of variation (CV) for drained weight was 1.7 for factory 1 and significantly higher 5.5, 6.7, 4.8, 4.0 for products from factory $2,3,4 \mathrm{a}, 4 \mathrm{~b}$.

Table 7. Example on determination of sugar inversion $(n=3)$.

\begin{tabular}{|c|c|c|c|c|c|c|}
\hline Sample & Brix, $100 \mathrm{~g}^{-1}$ & $\mathrm{pH}$ & Inversion, \% & Absorbance & Firmness, $\mathrm{kg}$ & YI-1 \\
\hline 1 & $20.3 \mathrm{c}$ & $3.85 \mathrm{~b}$ & $78.8 \mathrm{c}$ & $0.098 \mathrm{~d}$ & $355 \mathrm{a}$ & $47.4 \mathrm{e}$ \\
\hline 2 & $21.3 \mathrm{~b}$ & $3.60 \mathrm{c}$ & $85.7 \mathrm{c}$ & $0.099 \mathrm{~d}$ & $203 \mathrm{~b}$ & $62.7 \mathrm{~d}$ \\
\hline 3 & $20.9 \mathrm{~d}$ & $3.58 \mathrm{~d}$ & $94.7 \mathrm{~b}$ & $0.190 \mathrm{c}$ & $104 \mathrm{c}$ & $79.6 \mathrm{c}$ \\
\hline 4 & $19.7 \mathrm{~d}$ & $3.60 \mathrm{a}$ & $95.8 \mathrm{a}$ & $0.342 \mathrm{~b}$ & $66 \mathrm{~d}$ & $88.2 \mathrm{~b}$ \\
\hline 5 & $21.9 \mathrm{a}$ & $3.55 \mathrm{e}$ & $96.8 \mathrm{a}$ & $0.890 \mathrm{a}$ & $50 \mathrm{e}$ & $94.7 \mathrm{a}$ \\
\hline
\end{tabular}

The data from measurement of amount of brine varied from 4.1 in factory 1 , to significantly higher values 12.3, 15.1 for products from factory 2 and 3 and medium 7.3, 7.0 for factory $4 \mathrm{a}$ and $4 \mathrm{~b}$. Soluble solids was medium 3.4, 7.6, 5.2 in products from factory 1,3 and $4 \mathrm{a}$ and lowest 1.8, 3.4 for factory 1 , and $4 \mathrm{~b}$ and significantly highest 13.9 for factory 2 . The coefficient of variance for the drained weight and brine is significantly high because of the variation in amount of slices carried out firstly leaving various volumes for brine. That resulted in supply of different amounts of each ingredient in the jars from each factory, whereas the number of bottles with significantly different content was none for brine, drained weight and sucrose inversion and 1 to 3 for $\mathrm{pH}$, acetic acid, $\mathrm{NaCl}$ and soluble solids, respectively. The coefficient of variation was below $5 \%$ for soluble solids, acetic acid, $\mathrm{pH}$ and $\mathrm{NaCl}$, while brine, firmness, sugar inversion. A serious reason for the high variance coefficient in drained weight and brine are that different jar sizes were applied by production at the four factories. Cucumber firmness varied from 329.8 to $405.1 \mathrm{~kg}$. The contents of sugar varied from 15.8 to $23.4 \mathrm{~g}_{100 \mathrm{~g}^{-1}}$ that also may be related to differences regarding consumer preferences. The most interest may be the significantly differences in percentage inversion of sucrose to glucose and fructose that are related to high temperatures by brine preparation and long storage time at temperature with increasing sucrose. Dependence between these quality properties showed that drained weight increased significantly with the content of brine, the content of inverted sucrose increased with the content of soluble solids and firmness increased with increasing drained weight/brine resulting in decreases of soluble solids and acidity.

The data in table 7 shows significant differences in quality characteristics by processing of cucumber slices using five processing lines. It is clear that the differences in soluble solids are small in comparison to the differences in sugar inversion, firmness and the level of sugar inversion that varies from 47.4 to almost complete inversion of the applied sugar. These samples shows data from processing control showing how a failure may result in very unsatisfactory products and these data shows how easy it may be to secure processing qualities. Drained weight $=132.58+1.41$ brine; $r=0.884, \mathrm{P}<0.01$.Using a response surface methodology (RSM) analysis (Table 8) howed that drained weight increased significantly with blanching time $\mathrm{T}$ and significantly negatively related to the square of blanching time $\mathrm{T}^{2}$ 
showing that there must be a ridge. Drained weight was not affected by days of storage and increased significantly with blanching time and storage temperature. Firmness was negatively related to blanching time and to the interaction between storage months and blanching time. Firmness decreased significantly with blanching time (T) and because of the interaction between storage time and storage temperature (MT) and decreased with the square of blanching temperature $\left(\mathrm{T}^{2}\right)$.

Table 8. Constant, regressions coefficients and multiple correlation coefficients.

\begin{tabular}{|c|c|c|c|c|c|c|}
\hline Quality characteristics & & $\begin{array}{c}\text { Weight, } \\
\mathrm{g}\end{array}$ & Firmness, kg & $\begin{array}{c}\text { Lightness, } \\
\mathrm{L}\end{array}$ & $\begin{array}{c}\text { Greenness, } \\
\mathrm{a}\end{array}$ & $\begin{array}{c}\text { Yellowness, } \\
\mathrm{b}\end{array}$ \\
\hline Constant & $\mathrm{C}_{0}$ & 295.8 & 336.8 & 74.3 & -5.44 & 20.0 \\
\hline Storage days & $\mathrm{M}$ & & -1.42 & -0.44 & 0.19 & \\
\hline Blanching time, min & $\mathrm{T}$ & 53.8 & 65.6 & -5.69 & & -5.84 \\
\hline Storage temperature, ${ }^{\circ} \mathrm{C}$ & $\mathrm{C}$ & 0.4 & & -0.42 & 0.14 & 0.56 \\
\hline Storage days*blanching time & $\mathrm{MT}$ & & 0.94 & & & \\
\hline Storage days*storage temp & $\mathrm{MC}$ & & & & & \\
\hline Blanch time*storage temp. & $\mathrm{TC}$ & & -0.65 & 0.08 & & \\
\hline Storage days*storage days & $\mathrm{M} 2$ & & & & & \\
\hline $\begin{array}{c}\text { Blanchingtime*blanching } \\
\text { time }\end{array}$ & $\mathrm{T} 2$ & -10.7 & -25.9 & 0.75 & & \\
\hline Storage temp*storage temp & $\mathrm{C} 2$ & & & & & 1.51 \\
\hline Correlation coefficient & $\mathrm{R}$ & 0.95 & 0.87 & 0.94 & 0.81 & -0.01 \\
\hline
\end{tabular}

The interaction between storage time and storage temperature was found to be blanching time $2.5 \mathrm{~min}$ and increased with storage time while firmness decreased significantly by storage time. Data from the RSM analysis showed that change in drained weight by changed in storage temperature was $(\mathrm{dG} / \mathrm{dC})_{\mathrm{T}}$ $=0.39 \mathrm{~g} /{ }^{\circ} \mathrm{C}$ and by storage temperature $(\mathrm{dG} / \mathrm{dT})_{\mathrm{C}}=2.5 \mathrm{~min}$ was positive. Blanching for $0,1.3$ and 2.5 min resulted in 302,354 and $364 \mathrm{~g}$ drained weight corresponding to 90,101 and 108\%. Changing in firmness during storage temperature was negative $(\mathrm{dB} / \mathrm{dot})_{\mathrm{M}, \mathrm{C}}=-1.3 \mathrm{~min}$ as the change in firmness $(\mathrm{dH} / \mathrm{dC})_{\mathrm{M}, \mathrm{T}}=-0.84 \mathrm{~kg} /{ }^{\circ} \mathrm{C}$ and storage temperature was negative $(\mathrm{dH} / \mathrm{dM})_{\mathrm{T}, \mathrm{C}}=-0.20 \mathrm{~kg} / \mathrm{month}$. Change in greenness by storage time and blanching time $(\mathrm{da} / \mathrm{dM})_{C}=0.19 /$ month and blanching time $(\mathrm{da} / \mathrm{dC})=$ $.14 /$ month was positive. The changes in yellowness by blanching temperature $(\mathrm{db} / \mathrm{dT})_{\mathrm{C}}=0.14 / \mathrm{month}$ and storage temperature was positive $(\mathrm{db} / \mathrm{dC}) \mathrm{T}=0$ for $\mathrm{C}=16$. The storage temperature showed a maximum for blanching time $2.5 \mathrm{~min}$ and plotting of blanching time versus storage temperature resulted in the optimum firmness by blanching for $1.3 \mathrm{~min}$. There was a ridge for blanching time and storage temperature resulting in a maximum for drained weight by blanching for $2.5 \mathrm{~min}$ by storage temperature $15^{\circ} \mathrm{C}$. Another important decrease of quality characteristics is that the slices and brine often are brown and very soft that could be caused by increasing temperature by blanching. It was also hypothesized that browning could be due to enzyme activities that should be controlled by test for enzyme activities and very long storage time at to high temperatures. However, browning must also be due to the high percentage of sucrose inversion as shown for two factories that often causes browning due to reactions between fructose and nitrogen compounds. Pasteurization of cucumber slices at $80^{\circ} \mathrm{C}$ showed significantly decreases in both browning rate and firmness by blanching for more than 3-6 minutes.

Table 9. Response surface analysis by processing of sliced cucumber.

\begin{tabular}{|c|}
\hline Found explaining equations \\
\hline Drained weight $=296.00+53.82 \mathrm{~T}+0.39 \mathrm{C}-10.68 \mathrm{~T}^{2}$ \\
\hline Firmness $=320.00+71.21 \mathrm{~T}-0.65 \mathrm{TC}-25.9 \mathrm{~T}^{2}$ \\
\hline Lightness $=69.03-5.69 \mathrm{~T}-0.42 \mathrm{C}+0.08 \mathrm{TC}+0.75 \mathrm{~T}^{2}$ \\
\hline Greenness $=-5.44+0.19 \mathrm{M}+0.14 \mathrm{C}$ \\
\hline Yellowness $\mathrm{b}=20.02-5.85 \mathrm{~T}+0.56 \mathrm{C}+1.52 \mathrm{~T}^{2}-0.017 \mathrm{C}$ \\
\hline $\mathrm{dG} / \mathrm{dC})_{\mathrm{T}}=\mathrm{k}_{\mathrm{g} 3}=0.39 \mathrm{~g} /{ }^{\circ} \mathrm{C} ;(\mathrm{dG} / \mathrm{dT})_{\mathrm{c}}=2.5 \mathrm{~min}$ \\
\hline$(\mathrm{dH} / \mathrm{dC})_{\mathrm{MC}}=67.10-51.82 \mathrm{~T}=0$ for $\mathrm{T}=1.3 ;(\mathrm{dH} / \mathrm{dC})_{\mathrm{MT}}=-0.84 \mathrm{~kg} /{ }^{\circ} \mathrm{C}$ \\
\hline
\end{tabular}

Drained weight depended significantly of blanching time $(\mathrm{T})$, storage temperature $(\mathrm{C})$ and the square of blanching time (Table 9).Firmness was significantly associated to a constant (295.8), blanching time (T), interaction between storage time and blanching (MT), interactions between blanching time and storage temperature $(\mathrm{T})$ and negatively of blanching time $\left(\mathrm{T}^{2}\right)$. Lightness depended on storage time (M) storage temperature (C), storage temperature (C) and interaction between blanching time and storage temperature (TC) and negatively to the squared blanched time $\left(\mathrm{T}^{2}\right)$. Greenness depended 
on storage time (M) the squared blanching time. Firmness depended on storage temperature (C), storage time (M), storage temperature, two interactions (MT, TC) and negatively to the squared temperature $\left(\mathrm{T}^{2}\right)$. Lightness depended significantly interaction between blanching time and storage temperature (TC) and the squared blanching time $\mathrm{n}$ blanching time (M). Greenness depended on storage time $(\mathrm{M})$, while yellowness depended on blanching time and storage time (M), the squared blanching (T2) time and storage temperature(C2) (Table 9). Lightness depended significantly of storage time, blanching time, interaction between storage time and blanching time, interaction between blanching time and blanching time.

\section{REFERENCES}

[1] Bell T.A. Etchelles J.L. Jones I. D. 1950. Softening of commercial cucumber salt-stock in relation to Polygalacturonase activity. Food Technol. 4, 157-163.

[2] Etchells J.L. Bell T.A. Williams C.F. 1958. Inhibition of pectinolytic and cellulytic enzymesin cucumber fermentations by scuppernong grape leaves. 1958. Food Technol. 12, 204-208.

[3] Fasina O. Fleming H.P. Thompson, R.L.2002. Mass transfer and solute diffusion in brined cucumbers. Food Sci. 67,181-187.

[4] Nebesky K.A. Esselen W.B. Fellars C.R. 1951. Studies on the peroxidase in pickles and pears. J. Food Technol. 5, $110-113$.

[5] Hildrum R.H. 1972. Inflytelse av bestemte varmebehandlingsbetingelser på konsistensenav syrekonserverte drueagurker. Tidsskrift for Hermetikindustri 58, 75-77.

[6] Akbudak B. Ozer M. H. Uylaser V. Karaman, B. 2007.The effect of low oxygen and high carbon diooxideon storage and pickle production of pickling cucumbers cv. 'Octobus'. J. Food Eng. 78, 1034-1046.

[7] Überla K.Factorenanalyse (1971). Springer New York.

[8] Sharma S. 1996.Applied Multivariate Techniques. Wiley, New York.

[9] LampiA. Esselen B. Thomson C.L. Anderson E.E. 1958.Changes in pectic substances of fourvarie-ties of pickling cucumbers during fermentation and softening. J. Food Sci. 23, 351-363.

[10] TangL. McFeeters. 1983. Relationships among cell wall constituents, calcium and texture during cucumber fermentation and storage. J. Food Sci. 48, 66-70.

[11] McFeeters R. F. Pérez-Díaz I. 2010. Fermentation of cucumbers brined with calcium chloride instead of sodium chloride. J. Food Sci. 75, C291- C295.

[12] Hudson J.M. Buescher, R.W. 1986. Relationship between degree of pectin and tissue firmness of cumber pickles.J. Food Sci.51, 138-140.

[13] Pangborn R.S. Vaughn R.H. York G.K. Estelle M. 1959. Effect of sugar, storage time and temperature on dill pickle quality. Food Technol. 13,489-492.

[14] Fellers P. J. Pflug, I. J. 1968. Loss of whiteness from fresh cucumber pickles. Food Technol.22, 1601-1609.

[15] McFeeters, R.F. Pérez-Díaz 2010. Fermentation of cucumbers brined with calcium chloride instead of sodium chloride. J. Food Sci. 75, C291- C296.

[16] Schwartz, H.G. Chao R.Y. 1982. Solute diffusivities in leaching processes. Food Technol. 36, 73-86.

[17] Pflug I.J. Fellers P.I. Gurevitz D. 1967. Diffusion rates in the desalting of pickles. Food Technol. 21, 90-94.

[18] Pflug I. J. Fellers P. J. Gurevitz, D. 1967.Diffusion rates in the desalting of pickles. Food Technol. 21, 90-94.

[19] Pflug, I. J. Nicholas, R.C. 1961. Effect of blanching and holding treatment on the quality of fresh cu-cumber pickles. Mich. Agr. Expt. Sta. Quart. Bull. 44,70-76.

[20] Potts, E.A. Fleming, H.P. McFeeters R.F. Guinnup, D.G. 1986. Equilibration of solutes in non fermenting, brined pickling cucumbers. J. Food Sci. 51,434-439.

[21] Lespinard, A.R., Bon J., Cárcel, J.A. Mascheroni, R.H. 2015. Effect of ultrasonic-assisted blanching on size variation, heat transfer, and quality parameters of mushrooms. Food and Bioprocess Technology 8, 41-53. 
[22] Thompson, R.L., Fleming D.P. Monroe R.J. 1979. Effects of storage conditions on firmness of brined cucumbers. J. Food Sci. 44, 843-846.

[23] Turney M.P. Schoene E.S. 1969. Influence of various acidities and pasteurizing temperatures on the keeping quality of fresh-pack dill pickles. Food Technol. 23, 71-77.

[24] Cho, M.J. Buescher, R.W. 2012. Potential role of native pickling cucumber polygalacturonase in softening offresh pack pickles. J. Food Sci. 77, C443-C447.

[25] Demain, A.L. Phaff H.J. 1957. Inhibition of polygalacturonase softening of cucumber pickles by calcium chloride. J. Agric. Food Chem. 5, 60-64.

[26] Potts E.A. Fleming, H.P. Guinnup D.G. 1986. Equilibration of solutes in non-fermentingbrined pickling cucumbers. J. Food Sci. 51,434-439.

[27] Buescher, R,W.and C McGuire1986. Peroxidase activities in cucumber pickle products. J. Food Sci. 51, 1079-1080.

[28] Gandía-Herrero, F. M. Jiméz, J. CabanesF. Garcia-Carmona E. AcribanoJ. 2003. Tyrosinase inhibitory activity of cucumber compounds enzymes responsible for browning in cucumber. J. Agric. Food Chem. 51, 7764-7769.

[29] Turney and E.S Achone 1969. Influence of various acidities and pasteurizing temperatures on the keeping quality of fresh-pack dill pickles. Food Technol. 23. 71-77.

[30] Buescher, R.W., C. McGuire E and B. Skulman. 1987. Catalase, lipoxygenase and peroxidase activities in cucumber pickles as affected by fermentation, processing, and calcium chloride. J. Food Sci. 52 228-229. 